\title{
СТРИМ-ТРАНСЛЯЦІЯ ЯК НОВІТНІЙ СПОСІБ ВИСВІТЛЕННЯ НАДЗВИЧАЙНИХ СИТУАЦІЙ
}

\author{
Роксолана Кікерчук \\ Львівський національний університет імені Івана Франка, \\ вул. Генерала Чупринки, 49, 79044, Львів, Україна \\ e-mail: r.kikerchuk@gmail.com \\ https://orcid.org/0000-0002-0082-7118
}

У статті досліджено, як телеканали інформують громадськість про надзвичайні ситуації. З’ясовано, що ЗМІ використовують стрим-повідомлення під час висвітлення та передачі термінових повідомлень. Наведена кореляція між Революцією Гідності та початком використання стрим-трансляцій в Україні. Окреслено тематику надзвичайних подій, які передають за допомогою стриму.

Ключові слова: стрим-трансляція, прямий ефір, мобільна журналістика, надзвичайні ситуації, Революція Гідності, катастрофи.

У час зародження телебачення здавалося, що прямий ефір, як спосіб висвітлення подій, буде надзвичайно рідкісним та вибірковим. Натомість, поширення інформації за допомогою прямих ефірів стало багатовекторним. Протягом останніх кількох років трансляції подій в реальному часі $€$ центром багатьох інформаційних медіа-систем у всьому світі. Провідні інформаційні телеканали, як-от «Сi-Ен-Ен», «Бі-БіСі», «СвроНьюз» тощо працюють в режимі реального часу. Застосування технології прямої передачі даних вплинуло не тільки на специфіку журналістської роботи, а й на трактування новин аудиторією. Через це журналіста, який працює на місці події, в більшості випадків, аудиторія сприймає краще, ніж передачу сухих фактів зі студії телеведучими. Дослідники медіапростору підтверджують: трансляція новин «наживо» максимально зосереджує увагу реципієнта на події.

Багато різноманітних інформаційних організацій, включаючи застарілі мовники, надруковані застарілі носії та цілий ряд цифрових гравців, експериментують із різними телевізійними та онлайновими відео для охоплення аудиторії. Очевидно, телебачення здає позиції в порівнянні з тим, яких обертів набирає Інтернет. Через це телеканали застосовують новітні технології у своїх ефірах.

Дедалі більше медіапрацівників звертаються до концепції мобільної журналістики. Смартфони на сьогодні потужніші, їхні камери не поступаються багатьом професійним відеокамерам, а додатки для знімання, редагування та передачі візуальних звітів дозволяють журналістам випускати професійні матеріали навіть у режимі ре-

(C) Кікерчук Р., 2019

Наукове рецензування і рекомендація до друку - проф. Лизанчук В.В. 
ального часу. Журналісти вбачають у цьому можливість використовувати свої мобільні телефони як інструмент звітування перед громадськістю.

Це й стало визначальним фактором для працівників медіа під час Революції Гідності, з якої бере відлік стрим-журналістика в Україні. На прикладі Революції можна простежити як зароджувалась ідея висвітлення надзвичайних ситуацій за допомогою стрим-трансляції. В умовах збройного протистояння між активістами та силовиками «Беркуту», що діяли за наказом тодішньої злочинної влади, журналісти були змушені працювати під прикриттям, адже знаходитись у епіцентрі тих подій 3 позначкою «преса» було небезпечно для життя.

Стрим-трансляції досліджували: К. Сергацкова у статті «Стрим у часи воєнних дій», Є. Маранц в статтях «Стримери, які кидають виклик традиційній журналістиці», «Стрими, як нове явище в медіа комунікаціях». Більшість наукових праць, які стосуються явища стрим-трансляції, присвячені мовленню телеканалів, зокрема, монографія «Журналістська творчість на телебаченні» В. Гояна, посібник «Методи журналістики» Г.Мельника, автореферати дисертацій - «Діалогічна форма телебачення» Н. Черкасової та «Комунікативна культура прямого телевізійного ефіру» В. Дячук.

Крім того, досліджено особливості стрим-матеріалів на основі аналізу мовлення в прямому ефірі у статтях: «Прямий ефір: 3 чого все починалося» Е. Бабчук, «Соціокомунікаційні моделі телевізійних текстів прямого ефіру» О. Жука, «Контент інтерактивного мовлення» О. Ятчук тощо. Однак, існує брак глибинних досліджень феномену стрим-трансляції.

Журналісти досі сперечаються про те, де закінчується пряма трансляція в їі традиційному розумінні і починається стрим-трансляція. Дослідники медіапроцесів Е. Амірханов, В. Кравченко пропонують наступне визначення: «Live Stream» або «потокове мультимедіа» - це доставка мультимедійних потоків інформації (аудіо та відео) віддаленим користувачам у реальному режимі часу» [1].

Смислове наповнення стрим-матеріалів визначає кожен телеканал в залежності від своєї спрямованості та інтересів. Сдиним є те, що стрим-трансляції застосовуються під час висвітлення надзвичайних подій, або таких, які викликали суспільний резонанс і мають бути повідомлені вже і зараз. «Головною та визначальною рисою є надзвичайність подіï, ї̈ соиіальна значущість», - зазначає телеведучий В. Полуєв. «Стрим, в основному, цее вибух, мітинг, мари-хода, тобто те, щзо треба показати вже», - наголошує журналіст телеканалу «NewsOne» Я. Чуйко.

Основним критерієм для визначення, чи застосовувати до певної тематики технологію стрим-трансляцій є аналіз того, чи можна цю інформацію подати пізніше, чи потрібно повідомляти одразу. «Стрим завжди в пріоритеті над сюжетом, коли події розвиваються дуже швидко - тут і зараз. Якщзо є ризик, щуо до моменту, коли ти приїдеш в редакиію, надішлеш відео $і$ зробиш сюжет, подї зміняться - набагато краще робити стрім», - зазначає стример телеканалу «Громадське телебачення» О. Яриш.

Глядача, через надлишок інформації, важко чимось здивувати та захопити. Аудиторія звикла до максимально швидкої передачі даних і не готова чекати на новини. Саме тому телеканали активно використовують стрим-трансляції. Проте, це працює лише у випадку повідомлення резонансних подій, з динамічною картинкою. Тому стрим активно використовують телеканали під час висвітлення надзвичайних подій. 
Резонансні події, які передають журналісти у стрим-повідомленнях, викликають реакцію великої кількості людей (обурення, хвилювання, відгуки) на певні дії (інформація, поведінку, висловлювання) когось чи чогось. Професор С. Демченко слушно пропонує виходити за межі звичного, шукати резонансне, що дасть можливість «спалахнути», «прозвучати», «прогриміти», «засвітитись» [7, с. 300].

Резонують, як правило, надзвичайні події. Засоби масової інформації привертають увагу громадськості до надзвичайних ситуацій, коли вони призвели або можуть призвести до великої кількості жертв, становлять загрозу нормальному життю і діяльності груп людей, цілих регіонів чи навіть країн.

Отож, надзвичайні ситуації - це, зазвичай, аварії, катастрофи, стихійні лиха та інші події (епідемії, терористичні акти, збройні конфлікти тощо). Такі епізоди бувають природного, техногенного, соціально-політичного та воєнного характеру. Саме ця класифікація якнайкраще ілюструє тематично-змістове наповнення стрим-повідомлення інформаційних телеканалів, які використовують стрим-трансляції.

Надзвичайні ситуачії сочіально-політичного характеру - це ситуації, пов'язані з протиправними діями терористичного та антиконституційного спрямування: здійснення або реальна загроза терористичного акту (збройний напад, захоплення і затримання важливих об’єктів, систем зв'язку та телекомунікацій, напад чи замах на людей), викрадення (спроба викрадення) чи знищення об'єктів, встановлення вибухових пристроїв у громадських місцях, викрадення або захоплення зброї тощо [9].

Соціально-політичні події, які сколихнули державу, започаткували історію стрим-трансляцій в Україні, це епізоди Революції Гідності.

На початку Революції працівники медіа не очікували, що події розвиватимуться стрімко, тому не були готові технічно та організаційно. Через це був вигаданий формат стрим-трансляцій, щоб компенсувати брак техніки і кадрів. Тож журналістська робота вимушено стала спрощеною, а відтак мобільною. Крім того, журналісти звернулись до стрим-технологій через те, що пересування з габаритною технікою стало проблематичним, а розпізнавальні журналістські атрибути несли загрозу для життя. Оскільки преса була під прицілом злочинних угрупувань, які протидіяли Майдану.

22 листопада 2013 року Р. Скрипін, на той момент головний редактор «Громадського телебачення», в прямому ефірі заявив про початок мовлення [6]. Цього ж дня телеканал здійснив свою першу стрим-трансляцію з київського Євромайдану [5]. Стрим-трансляція в перший день існування телеканалу була спрямована передати атмосферу, яка панує на Майдані, несла революційний меседж. Крім того, під час трансляції постійно чути з рупору агітаційні промови відстоювання державницьких позицій. Стример $є$ безпосереднім учасником тих подій, знаходиться серед натовпу. Варто загадати, що з перших днів існування «Громадське» усіляко підтримувало позицію Євромайдану, пропагуючи ідею революції в своєму ефірі.

Підсумовуючи Революцію Гідності як генератора ідеї та концепції стрим-трансляції, можна стверджувати, що теми, які висвітлюють телеканали за допомогою стрим-трансляцій $є$ надзвичайні та знакові для суспільства. Події Революції вимагали постійного оновлення інформації, адже зміни відбувались кожної хвилини. Крім того, тематика Революції Гідності включала певні винятки у стандартах журналістської роботи, як-от можливість трансляції тіл загиблих та їх імен. У революційний час ці кадри є красномовним показником злочинності влади. 
Ілюстрація імен загиблих, що були написані на шматках паперу на тілах, під час стриму «Громадського телебачення» [2], хоч за міжнародними стандартами заборонена (родичі загиблих не мають дізнаватись про смерть рідних з телеекранів), але у цьому випадку деталізована інформація не лише можлива, а й повинна бути розголошена, оскільки йдеться про імена людей, які стали для держави героями.

Революція Гідності сформувала у телеканалів розуміння, що надзвичайні події потребують негайного реагування. Стрим-трансляція стала основним способом висвітлення резонансних та соціально значущих тем.

Надзвичайні ситуації воєнного характеру - це ситуації, пов'язані з наслідками застосування зброї масового ураження або звичайних засобів ураження. Крім того до надзвичайних військових ситуацій належить збройних напад іншої держави, збройний переворот тощо [9]. Тему військових дій намагались висвітлювали журналісти-стримери в зоні АТО на початку конфлікту. Однак, у відкритому доступі цих трансляцій практично не збереглось - їх прибрали через певні обмеження інформації у військовий період. Тож під час роботи в зоні бойових дій потрібно враховувати специфіку повідомлень у військовий час.

Зараз існує напрацьована схема передачі даних із зон окупації, але на початку антитерористичної операції журналісти не мали цього чіткого розуміння. Кореспонденти телеканалів інформували просто з місць дислокацій українських військових, ігноруючи жорстку заборону показу місць розташування, адже інформацію з українських телеканалів дізнаються не лише українці, а й терористи. До прикладу телеканал «Громадське телебачення» ілюстрував бої за Металіст 17 червня 2014 року [3]. В матеріалі журналістка ілюструє локацію військової бази. Основа трансляції - це розмова кореспондентки з військовими, яка з'ясовує їх історію, походження, їх переживання.

18 квітня 2014 року «Громадське» здійснювало стрим-трансляцію 3 с. Весела Гора Луганської області [10], коли бій навколо обласного центру і на околицях Луганська тривав вже кілька днів. Під час стрим-трансляції журналістка показала глядачам побут військових. З'ясувалось, що військові жили у земельних бліндажах. «Звуки градів тут не стихають ні на годину і так вже майже тиждень», - наголосила під час стриму журналістка. Крім того в фокус трансляції потрапили й поранені солдати, добре видно їхні закривавлені ноги. На завершення військові демонстрували техніку і готувалися до обстрілу терористів.

Варта уваги історія прямого включення журналіста, який перебував на дорозі до Дебальцево. Під час повторювання журналістом стенд-апу локацію, де перебувала команда «112 Україна» обстріляли бойовики. Рештки розірваної гранати потрапили в руку водієві. Його екстрено доставили у госпіталь Краматорська. Тоді журналіст вийшов в ефір з інформацією про цей факт [8]. «Сьогодні ми на власному досвіді побачили як на Донбасі зберігається, чи триває режим припинення вогню», зазначив журналіст під час включення. Після цієї історії телеканал «112 Україна» включення зі зони бойових дій не здійснював. Тож висвітлення подій в зоні АТО тепер - це сюжети, репортажі, чи інші вже зафільмовані повідомлення.

Телеканал «112 Україна» здійснював стрим-трансляцію з місця аварії Боїнга 17 липня 2014 року [13]. Журналіст потрапив на місце події пізно увечері, і хоч в кадрі опинилися тіла жертв, про що стример зазначив під час трансляції, відсутність 
освітлення і погана якість зв'язку сприяли тому, що пошматовані тіла загиблих неможливо розрізнити на зображенні.

Надзвичайні ситуаиії техногенного характеру - це транспортні аварії (катастрофи), пожежі, неспровоковані вибухи чи їх загроза, аварії з викидом (загрозою викиду) небезпечних хімічних, радіоактивних, біологічних речовин, раптове руйнування споруд та будівель, аварії на інженерних мережах і спору дах життєзабезпечення, гідродинамічні аварії на греблях, дамбах тощо. Тематика техногенних катастроф одна з провідних і найчисленніших змістових наповнень стрим-трансляцій телеканалів [9]. Це зумовлено тим, що такі трагедії є топ-темами ефірного мовлення. До прикладу, «Грибовицька трагедія» 3 обвалу нечистот і, як наслідок, загибелі людей, трансформувалась в багатомісячну тему колапсу зі сміттям, яку постійно експлуатували кореспонденти телеканалів в стрим-трансляціях. Проте найбільше уваги до «Грибовицького» було прикуто у перші дні трагедії.

Стримери «Громадського» висвітлювали трагедію Грибовицького сміттєзвалища [11], в прямому ефірі з'ясовували обставини в очевидців, в представників влади та ДСНС, а стрим-трансляції ведучі обговорювали у прямому ефірі з експертами.

Телеканал «112 Україна» здійснював стрим-трансляції від початку пожежі на Грибовицькому сміттєзвалищі, коли гірники ще не потрапили під завал. Найактивніше стрим-трансляції телеканал використовував в перші дні трагедії на сміттєзвалищі. Передавали стрим-матеріали, як і «Громадське», не лише безпосередніх подій, а й заяви представників влади, які прибували на місце події та жителів Грибовичів [12]. Через поганий зв’язок стримери телеканалу «112 Україна» часто «включались» за допомогою смартфона, проте без зображення, транслювали так званий «хрип»аудіоповідомлення.

Техногенні катастрофи, в переважній більшості, спершу висвітлюють журналісти-стримери. У випадках надзвичайних ситуацій стрим-трансляція передує іншим журналістським матеріалам, на кшталт сюжету, відео-замітки, репортажу тощо.

6 червня 2015 року «Громадське» здійснювало стрим-трансляцію пожежі на нафтобазі під Васильковом [14]. Журналіст транслював ситуацію на околицях нафтобази, з'ясовуючи всі можливі деталі: свідчення очевидців, жителів ближніх районів, представників влади тощо. Крім того передавав власні відчуття і враження 3 місця події.

2 березня 2017 року «NewsOne» стрим-транслював про трагедії на шахті «Степова» в Червонограді Львівської області [15]. В переважній більшості про обвал шахти розповідали журналісти в прямих включеннях. Проте телеканал використовував кадри шахти в полівікні, проте цих матеріалів небагато, оскільки зображення не $\epsilon$ динамічним. Стрим у ефірі змальовує рятувальників, трансляція потрапила лише у найменше полівікно телеканалу. Стрим-трансляції відбувались також з лікарні, в якій перебували постраждалі шахтарі. Таким чином «NewsOne», використовуючи стрим з декількох локацій, компенсував брак динаміки зображення подій.

Варте уваги стрим-повідомлення телеканалу «112 Україна» про вибух автомобіля на «Бесарабці» з Тимуром Махаурі [4]. Журналістка телеканалу перебувала поблизу підірваної автівки, тож одразу розпочала трансляцію, роз'яснюючи факти події, як очевидець. Під час стрим-трансляції журналістка спілкувалась зі свідками, брала коментарі у представників влади, які прибули на місце події. Протягом дня тривала стрим-трансляція, i, врешті, перетворилась на імпровізоване ток-шоу. 
Увечері ведучі телеканалу виїхали на місце трагедії і вели ефір «прайму» просто 3 вулиці. Тож існують випадки, коли стрим-трансляції надзвичайних подій трансформуються у цілий проект ефірного мовлення.

Висновки. Нові технології впливають на специфіку роботи під час прямого ефіру. Вміння використовувати для роботи мобільний телефон - це функція кожного громадянського журналіста. Стрим-трансляції, які передбачають мобільність журналіста, $\epsilon$ не лише потужним засобом впливу на громадськість, а технологією, яка в подальшому зможе відкрити шлях до нової журналістики, змінить її стандарти та вимоги до професії.

На прикладі Революції Гідності простежено кореляцію політичних змін та роботи інформаційних телеканалів. ЗМІ не очікували такого стрімкого розвитку подій, тому не були готові технічно та організаційно до їх висвітлення. Це спонукало медіа вигадати формат стрим-трансляцій, щоб компенсувати брак техніки і кадрів. Журналістська робота стала мобільною. Підсумовуючи Революцію Гідності як генератора ідеї та концепції стрим-трансляції, можемо стверджувати, що теми, які висвітлюють телеканали за допомогою стрим-трансляції, є надзвичайні та знакові для суспільства події.

Тематика надзвичайних ситуацій техногенного характеру стрим-трансляцій це транспортні аварії, пожежі, неспровоковані вибухи чи їх загроза, аварії з викидом небезпечних хімічних, радіоактивних, біологічних речовин, раптове руйнування споруд та будівель, аварії на інженерних мережах і спорудах життєзабезпечення, гідродинамічні аварії на греблях, дамбах тощо. Ці теми розглянуто на прикладах стрим-повідомлень з Грибовицького сміттєзвалища, вибуху на нафтобазі, та обвалу шахти «Степова» у Львівській області. Крім того, на прикладі стрим-матеріалів вибуху авто Т. Махаурі в центрі Києва з'ясовано, що стрим-повідомлення можуть переростати в імпровізовані тематичні ток-шоу.

Телеканали застосовують стрим-трансляції, коли висвітлюють надзвичайні події, або соціально значущі події, про які потрібно негайно повідомити. Стрим-повідомлення здійснюються за принципом інформаційного приводу. Тобто відбувається подія, яка має певний резонанс, а телерепортер ретранслює ії. Темами, які висвітлюють телеканали за допомогою стрим-трансляції, є надзвичайні та знакові для суспільства події. Стрим-трансляції з теперішньої російсько-української війни мають суворі обмеження і наразі їх не практикують.

Інформаційним наповненням стрим-трансляції має бути головне повідомлення, одна наскрізна тема та представлення героїв, їхня діяльність, те, що вони говорять та як реагують на запитання журналістів. Важлива роль і стримера, який мав би, окрім об'єктивного фактажу та вміння під неординарним кутом висвітлити подію, подавати різні погляди на неї та завжди посилатись на конкретні та достовірні інформаційні джерела. 


\section{REFERENCES}

1. Амірханов Е. Д. Аналіз технологій передачі даних, що використовуються в Інтернеті[Електронний ресурс]/Е.Д. Амірханов, В.І.Кравченко//Журнал «Науковий огляд». 2015. - Режим доступу до ресурсу: http://oaji.net/articles/2016/797-1464464795. pdf

2. Барикади, Грушевського, тіла загиблих. Hromadske.doc [Електронний pecypc] // Громадське телебачення. - Режим доступу до ресурсу: https://www.youtube.com/ watch? $=\mathrm{v} 5 \mathrm{fvza} 5 \mathrm{w} 5 \mathrm{iU}$

3. Бої за Металіст [Електронний ресурс] // Громадське телебачення. - Режим доступу до ресурсу: https://www.youtube.com/watch?v=G58fQ-ZAwUsM

4. Відео з місця вибуху автомобіля Т.Махаурі [Електронний ресурс] // Телеканал «112 Україна». - Режим доступу до ресурсу: https://112.ua/video/video-s-mestavzryva-avtomobilya-v-kieve-247552.html

5. Громадське ONLINE. Євромайдан 22 листопада. Перший ефір Громадського Телебачення [Електронний ресурс] // Громадське телебачення. - Режим доступу до pecypcy: https://www.youtube.com/watch?v=EH-n3Ayqctk\&index=5\&list=PLPnX89f QLdskBblrRQbEqCjUXEZ_TqrL8

6. Громадське ТБ: «Все гірше, ніж ви думаєте, але надія є» [Електронний ресурс]. - Режим доступу до pecypcy: http://stv.detector.media/reformuvannya/internet/ gromadske_tb_vse_girshe_nizh_vi_dumaete_ale_nadiya_e/

7. Демченко С.В. Масова комунікація як чинник формування громадянського суспільства в незалежній Україні (глобальне і національне): монографія / С.В. Демченко. Дніпропетровськ: Вид-во Маковецький, 2009. 368 с.

8. І вся команда 112 [Електронний ресурс] // Телеканал «112 Україна».-Режим доступу до ресурсу: https://ua.112.ua/video/dokumentalnyi-film-i-vsia-komanda-112-255038. html

9. Класифікація надзвичайних ситуацій [Електронний ресурс] - Режим доступу до pecypcy: http://posibnyky.vntu.edu.ua/bjd/61.htm

10. Луганськ в облозі [Електронний ресурс] // Громадське телебачення. - Режим доступу до ресурсу: https://www.youtube.com/watch?v=uuVS4gkq5t

11. Масштабний обвал сміття поховав під собою рятувальників [Електронний ресурc] // Громадське телебачення. - Режим доступу до ресурсу: https://www.youtube. $\mathrm{com} /$ watch? $\mathrm{v}=\mathrm{iDd} 2 \mathrm{emfZmr} 8$

12. На Грибовицькому сміттєзвалищі тривають пошуки рятувальників [Електронний ресурс] // Телеканал «112 Україна». - Режим доступу до ресурсу: https:// ua.112.ua/video/na-hrybovytskomu-smittiezvalyshchi-vidnovylysia-poshuky-trokhriatuvalnykiv-turovtsev-1980.html

13. Падіння Боїнга 777. Хронологія подій [Електронний ресурс] // Телеканал «112 Україна». - Режим доступу до ресурсу: https://112.ua/avarii-chp/krusheniemalaziyskogo-boinga-hronologiya-sobytiy-89710.html

14. Пожежа на нафтобазі [Електронний ресурс] // Громадське телебачення. - Режим доступу до ресурсу: https://www.youtube.com/watch?v=HmLk0Y-6sfY

15. Трагедія на шахті «Степова» [Електронний ресурс] // NewsOne. - Режим доступу до ресурсу: https://www.youtube.com/watch?v=JxJ7OIZuj 


\title{
LIVE STREAMING AS A NEW METHOD COVERAGE OF EMERGENCY RESPONSE
}

\author{
Roksolana Kikerchuk \\ Ivan Franko National University of Lviv, \\ Chuprynky Str. 49, 79044, Lviv, Ukraine \\ e-mail: r.kikerchuk@gmail.com \\ https://orcid.org/0000-0002-0082-7118
}

More and more media are turning to the concept of mobile journalism. Smartphones today are more powerful, their cameras are not inferior to many professional video cameras, and applications for removing, editing and transferring data allow journalists to produce professional materials in real time.

This has become a determining factor for media workers during the Revolution of Virtue, which is being taken by journalism in Ukraine. On the example of the Revolution it is possible to trace how the idea of the coverage of emergencies was born with the help of streaming broadcast. In conditions of armed confrontation between activists and security officials of Berkut, journalists were forced to work under cover, as being in the epicenter of those events marked «press» was life-threatening.

The semantic content of the stream material is determined by each television channel depending on its orientation and interests. The only thing is that streaming broadcasts are used during the coverage of extreme events, or those that have caused public resonance and should be reported already and now.

The topics that streamline TV channels are extraordinary and socially significant events. The focus of the strain-message is man-made disasters, emergencies of a socio-political nature and armed conflicts.

Key words: streaming broadcast, live broadcast, mobile journalism, emergency situations, Revolution of Dignity, catastrophe. 